\title{
Using quantitative proteomic analysis to understand genotype specific intrinsic drug resistance in melanoma
}

\author{
John M. Koomen ${ }^{1,2} \&$ Keiran S. M. Smalley ${ }^{1,3,4}$ \\ ${ }^{1}$ Program in Molecular Oncology, The Moffitt Cancer Center \& Research Institute, Tampa, FL, USA \\ ${ }^{2}$ Program in Experimental Therapeutics, The Moffitt Cancer Center \& Research Institute, Tampa, FL, USA \\ ${ }^{3}$ Program in Cutaneous Oncology, The Moffitt Cancer Center \& Research Institute, Tampa, FL, USA \\ ${ }^{4}$ The Comprehensive Melanoma Research Center, The Moffitt Cancer Center \& Research Institute, Tampa, FL, USA \\ Correspondence to: Keiran S. M. Smalley, email: keiran.smalley@moffitt.org \\ Keywords: Oncogene, cancer, kinase, BRAF V600E, drug resistance, proteomics
}

Received: April 13,2011,

Accepted: April 14, 2011,

Published: April 15, 2011

Copyright: () Koomen et al. This is an open-access article distributed under the terms of the Creative Commons Attribution License, which permits unrestricted use, distribution, and reproduction in any medium, provided the original author and source are credited.

ABSTRACT:

\begin{abstract}
The discovery of activating BRAF V600E mutations in $50 \%$ of all melanoma patients and the development of small molecule BRAF inhibitors looks set to revolutionize the therapy of disseminated melanoma. However, in the recent clinical trial of the BRAF inhibitor, vemurafenib (PLX4032), a significant percentage of BRAF V600E mutant melanoma patients did not meet the RECIST criteria for a response. Recent work from our lab identified loss of the tumor suppressor phosphatase and tensin homolog (PTEN) as being a possible mediator of intrinsic BRAF inhibitor resistance. In this commentary, we describe the development of a novel mass spectrometry based proteomic screen of $\mathrm{Bcl}-2$ family proteins that was used to delineate the PTENdependent differences in apoptosis signaling observed when BRAF was inhibited. We further discuss how use of these sensitive quantitative proteomic methods gives unique insights into the signaling of cancer cells that are not captured through routine biochemical techniques and how this may lead to the development of combination therapy strategies for overcoming intrinsic BRAF inhibitor resistance.
\end{abstract}

\section{TARGETED THERAPY IN MELANOMA}

Melanoma is the deadliest form of skin cancer. It arises from the malignant transformation of melanocytes and has long been notorious for its resistance to chemotherapy, radiotherapy and immunotherapy. In recent years, great strides have been made in our understanding of the underlying genetic and biological basis of melanoma initiation and development. We now stand at an exciting juncture in melanoma research in which our accumulated knowledge about melanoma biology is translating into new therapeutic strategies. One key discovery of the last decade is the identification of activating mutations in the serine/threonine kinase BRAF in up to $50 \%$ of all melanomas [1]. There is now good evidence that mutated $B R A F$ is a key initiating event in melanoma development and that continuous BRAF signaling is required for melanoma progression $[2,3]$. Most of the transforming activity of mutant $B R A F$ is mediated through the activation of the RAF/MEK/ERK signaling pathway which drives cell cycle dysregulation and uncontrolled growth by reducing expression of the cyclin dependent kinase inhibitor p27 and by increasing the expression of cyclin D1 $[4,5]$. In addition to its effects upon cell growth, mutant $B R A F$ also contributes to the oncogenic phenotype of melanoma cells through both down regulation of apoptotic signals and enhancement of cell invasion [6-9]. Recent clinical studies have demonstrated that the presence of a $B R A F$ mutation is prognostic for melanoma and is associated with reduced survival in the metastatic setting [10].

The discovery of activating BRAF mutations in melanoma prompted a flurry of drug discovery activity and the development of small molecule BRAF inhibitors. The list of BRAF inhibitors currently undergoing preclinical and clinical evaluation includes XL281, SB590885, GDC-0879, GSK2118438, AZ628 and PLX4032 [11-14]. Of these, PLX4032 (vemurafenib) and its analog, PLX4720, have been most extensively studied $[13,15-18]$. Treatment of melanoma cell lines and mouse 
xenografts with PLX4032/4720 led to both G1 phase cell cycle arrest and the induction of apoptosis [13, 15]. The effects of PLX4032 were noted to be BRAF mutation specific, and equivalent responses were seen in melanoma models with both heterozygous and homozygous $B R A F$ mutations [13]. No anti-proliferative or cytotoxic effects were observed in melanoma cell cultures that lacked the $B R A F$ mutation. Interestingly, not all $B R A F$ mutated melanoma cell lines were similarly sensitive to PLX4032 and PLX4720 though, with some cell lines exhibiting intrinsic resistance [17-19].

In the phase I clinical trial, vemurafenib led to significant levels of tumor shrinkage in $80 \%$ of patients whose melanomas harbored the $B R A F$ V600E mutation [20]. This was an unprecedented result for a melanoma clinical trial and quickly led to the initiation of both phase II and phase III single agent trials [21]. The phase III trial of vemurafenib closed early when the primary progression free survival endpoint was met and the data has been submitted to the FDA for regulatory approval. Although the results from the vemurafenib trial were very impressive, responses were unfortunately shortlived with most patients ultimately failing therapy and becoming resistant (median progression free survival $\sim 7$ months) [20]. The development of strategies to manage and overcome acquired BRAF inhibitor resistance is now the major challenge facing the melanoma research community.

The emerging evidence suggests that acquired resistance to vemurafenib is complex and multi-factorial [17, 22-26]. Already, studies have shown that resistance can be mediated via increased receptor tyrosine kinase (RTK) signaling, the acquisition of activating mutations in $N R A S$, novel mutations in MEK1 and up regulation of MAP3K8 (Cot) [22-26]. Although the resistance mechanisms reported thus far are diverse, most are associated with the re-establishment of MAPK signaling and/or an increase in $\mathrm{PI} 3 \mathrm{~K} / \mathrm{AKT} / \mathrm{mTOR}$ signaling [2226]. Clinical trials are currently ongoing to validate the combination of BRAF and MEK inhibitors in $B R A F$ V600E mutant melanoma, with trials on the combination of BRAF with AKT inhibitors due to commence in the near future. The end goal of these studies is to define an optimal combination therapy strategy with the aim of extending the time to relapse and improving overall survival.

\section{USING PROTEOMICS TO UNDERSTAND THE MECHANISMS OF INTRINSIC BRAF INHIBITOR RESISTANCE}

Approximately $20 \%$ of $B R A F \quad \mathrm{~V} 600 \mathrm{E}$ mutant melanoma patients on the phase I trial of vemurafenib appeared to be intrinsically resistant and did not meet the RECIST criteria for a response [20]. Although uniquely addicted to MAPK signaling, melanomas are also known to require signaling activity in many other pathways, with the PI3K/AKT pathway thought to be particularly important for both melanoma initiation and progression $[2,27,28]$. In a recent study, our lab identified loss of expression of the tumor suppressor phosphatase and tensin homolog (PTEN) as being predictive for an impaired apoptotic response when BRAF was inhibited [29]. Mechanistically it was noted that inhibition of BRAF in PTEN null melanoma cells was associated with an increase in phospho-AKT expression which led in turn to the decreased nuclear accumulation of FOXO3a [29].

As no studies had yet addressed the mechanism by which PTEN expression regulated the apoptotic response following BRAF inhibition, we developed a novel mass spectrometry based technique to simultaneously quantify a large panel of Bcl-2 family proteins. As our approach, we used selected reaction monitoring mass spectrometry (SRM-MS), a method that was originally developed to enable quantification of analytes in complex mixtures. This technology (LC-SRM-MS) has been applied to the detection and quantification of small molecules (MW < $500 \mathrm{Da}$ ) for decades, and is used routinely to test for drugs of abuse and performance enhancement and to define pharmacokinetics and pharmacodynamics of therapeutic compounds. It was first applied to endogenous peptides in the early 1990's [30]. However, the use of triple quadrupole mass spectrometers to monitor proteolytic peptides as surrogates for the expression of a protein was first described in 1996 [31]. LC-MRM with the addition of spiked stable isotope labeled peptides enables quantification of the number of moles (or molecules) of the endogenous protein; this method has been termed absolute quantification (AQUA) [32-34]. It is important to note that this technique establishes a minimum value for the amount of the protein as the digestion and peptide recovery are incomplete (although they are extremely consistent).

When analyzing multiple fragments from different molecules, the technique is also called multiple reaction monitoring mass spectrometry (MRM-MS). The "reaction" is the conversion of the intact molecule into fragment ion(s) specific for its structure (see Figure 1A); this molecule-fragment pair is also termed a transition. Each "reaction" is optimized by the choice of background gas (typically argon or nitrogen) the pressure in the collision cell, and the collision energy applied. When coupled with reversed-phase liquid chromatography, three characteristics of the molecule are used to isolate its signal for detection and quantification: hydrophobicity (which defines the elution time), the mass-to-charge ratio $(\mathrm{m} / \mathrm{z})$ of the intact molecule, and fragment ion mass-to-charge ratio.

This research arena is extremely active and competitive; methods for assessment of panels of protein biomarkers and pipeline development have been described in recent publications [35-39]. Furthermore, LC-MRM 
shows promise in translation to the assessment of patients. Of equal importance, LC-MRM can be effective in elucidating biological processes; this technology has been used to monitor protein post-translational modifications as well as signaling networks [40-42]. Our study used SDSPAGE protein fractionation combined with LC-MRM detection and quantification to evaluate the expression of apoptosis-regulating proteins in the Bcl-2 family. The quantification of multiple family members is critical due to the redundancy of their function, and LC-MRM has the capability to measure large numbers of low abundance proteins in a single experiment. Quantification of these proteins revealed a differential up regulation of BIM between the PTEN expressing and PTEN null cells when BRAF was inhibited (14-fold increase vs 4-fold increase, respectively) (Figure 1B) [29].
BIM is a pro-apoptotic BH3-only domain protein that is regulated both transcriptionally and posttranscriptionally by many signaling pathways including BRAF/MEK/ERK, PI3K/AKT, p38 MAPK and JNK/ SAPK [43]. It exerts its pro-apoptotic effects by binding to and antagonizing the anti-apoptotic proteins Bcl-2, Bcl-w, Bcl-XL and Mcl-1 [44, 45]. In BRAF mutant melanoma cells, inhibition of BRAF using small molecule inhibitors and siRNA knockdown leads to the induction of apoptosis via a mechanism involving the decreased phosphorylation of BAD at Ser-75, an upregulation of BMF and an increase in BIM expression [6, 46, 47]. The identification of BIM as a key PTEN-regulated apoptotic mediator in $B R A F$ mutant melanoma cells allowed a novel mechanism of intrinsic drug resistance to be elucidated whereby the paradoxical activation of AKT in PTEN null cells led to a suppression
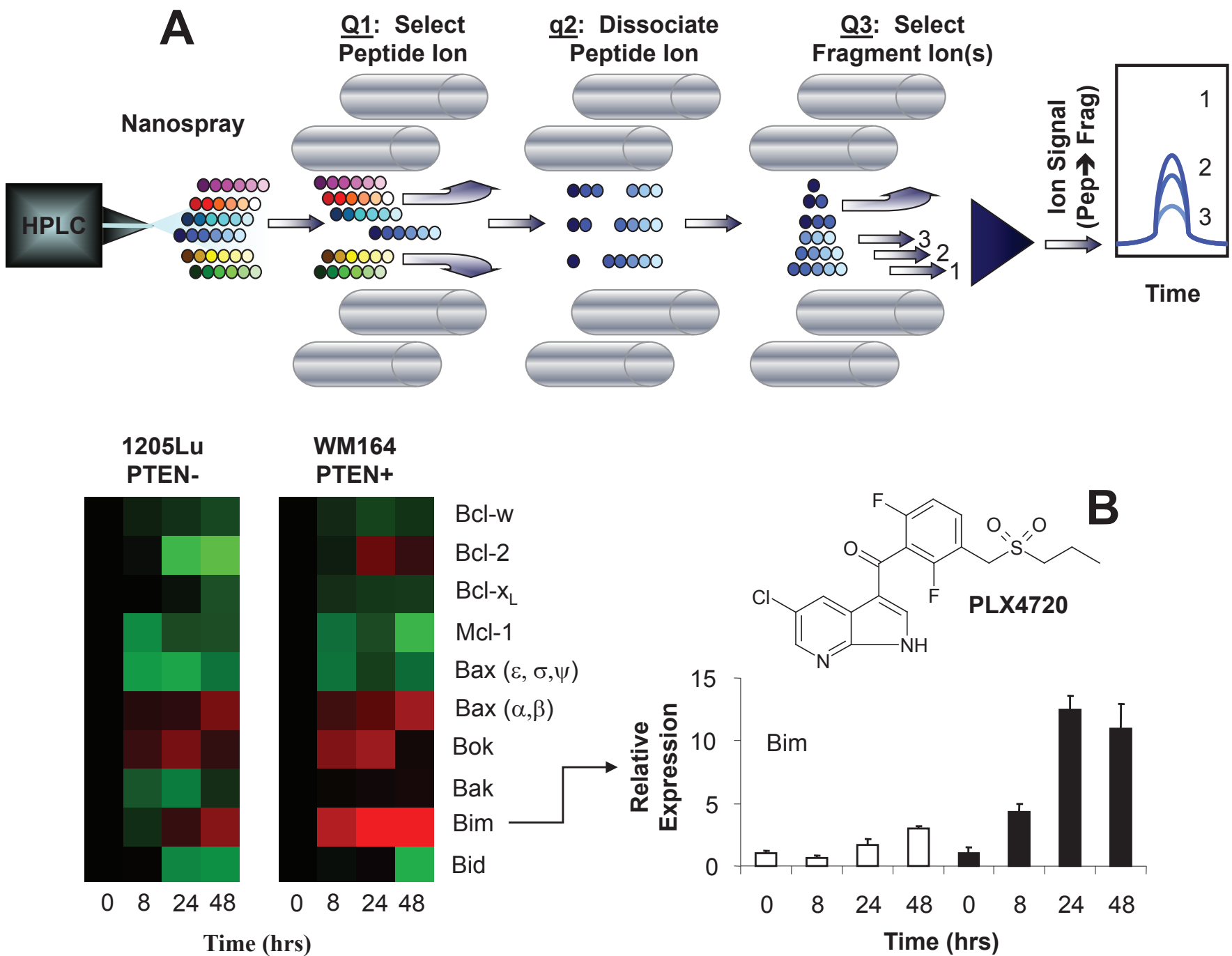

$\operatorname{Bax}(\varepsilon, \sigma, \psi)$
$\operatorname{Bax}(\alpha, \beta)$

$\operatorname{Bax}(\alpha, \beta)$
Bok
Bak
Bim $\square$

Bid

Time (hrs)
15
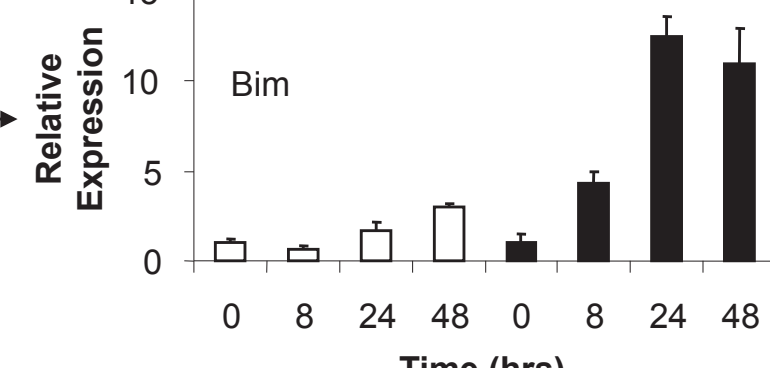

Figure 1: Liquid Chromatography Multiple Reaction Monitoring Mass Spectrometry: Principle and Practice. After reversed-phase HPLC separation, peptides are selected by their mass-to-charge ratio and dissociated by collisions with background gas before the fragment ions are mass selected to enable specific detection and quantification of individual peptides in complex mixtures (A). This technique was applied to the measurement of expression of apoptosis-regulating proteins in the Bcl-2 family to determine the mechanism for PTEN null melanoma cells' resistance to the BRAF V600E inhibitor, PLX4720 (inset). Both the heat map and the bar graph indicate that the major difference between the two cell lines was the upregulation of Bim, which caused apoptosis in PTEN positive cells. Regulation of the other Bcl-2 family proteins was similar regardless of PTEN status. 
of the nuclear accumulation of $\mathrm{FOXO} 3 \mathrm{a}$ and a reduction in BIM mRNA [29]. Of potential clinical relevance it was noted that dual inhibition of both BRAF and PI3K restored nuclear FOXO3a accumulation, upregulated BIM expression at the mRNA and protein levels and enhanced the level of apoptosis [29]. Similar results were also noted in melanoma cells intrinsically resistant to the MEK inhibitor AZD6244, where sensitivity could be restored by the dual inhibition of both MEK and IGF1R, mTORC1/2 or AKT [48]. Further support for the role for AKT signaling in intrinsic BRAF inhibitor resistance came from other studies showing that overexpression of an active form of AKT3 (myristolated AKT3) prevented apoptosis in $B R A F \mathrm{~V} 600 \mathrm{E}$ mutant melanoma cells when BRAF was inhibited [49].

The use of LC-MRM allowed the level of BIM expression to be identified as a PTEN-dependent determinant of BRAF inhibitor mediated apoptosis. If it were not for the exquisite sensitivity of the LC-MRM approach and the ability to accurately quantify peptide levels, the PTEN dependency of BIM expression in this process may not have been realized. The utility and value of LC-MRM comes primarily from the fact that experiments can be designed to evaluate the full complexity and detail of biological processes in different human disease states.

\section{CURRENT VALUE AND PROJECTED FUTURE POTENTIAL OF LC-MRM PROTEIN QUANTIFICATION}

Quantitative mass spectrometry, particularly LCMRM, is emerging as an alternative to antibody-based methods for the detection and quantification of proteins (such as Western Blotting). The development of peptidebased assays for protein expression, modification, and even mutations can be implemented very rapidly [50]. The selection of the target peptide sequence from either existing tandem mass spectrometry data or LC-MRM screening of peptide candidates, synthesis of stable isotope-labeled standards, and analysis to examine the match between the elution time and fragmentation patterns of the endogenous and standard peptide can be completed within a few days. Current mass spectrometers can analyze hundreds to thousands of transitions (peptide and fragment pairs) in each experiment enabling quantification of numerous proteins. While one peptide could be used as a surrogate, typically three or more transitions from three or more peptides are recommended for quantifying protein expression. Unlike antibody-based methods that are completely reliant on the reagents and the epitopes that they recognize, protein measurements with LC-MRM have a great deal more flexibility [51]. If an assay has interference, additional steps can be taken to change the protein purification, select another peptide, or even just select a different fragment ion from the same peptide. Through its versatility and capacity for multiplexing, LC-
MRM platforms should soon emerge as competitors for array technologies. Just as peptide sequencing with liquid chromatography-tandem mass spectrometry (LC-MS/ MS) has revolutionized biology, the ability of LC-MRM to detect and quantify low abundance targets determined a priori represents the next potential impact that proteomics can have on the study of human disease. As we have demonstrated, these methods have particular utility in unraveling how the genetic makeup of cancer cells can dictate drug response. As cancer therapy becomes ever more personalized, and the LC-MRM technology becomes more sophisticated, a future can be envisioned in which the key determinants of drug response can be determined in individual patient samples. It is hoped that these new approaches could allow therapies to be specifically tailored to individual patients so that efficacy can be maximized and off-target effects minimized.

\section{ACKNOWLEDGEMENTS}

Research in the Smalley lab is supported by The Harry Lloyd Trust, The Bankhead-Coley Research Program of the State of Florida (09BN-14) and the NIH/ National Cancer Institute (U54 CA143970-01). The Moffitt Proteomics Facility is supported by the US Army Medical Research and Materiel Command under Award No. DAMD17-02-2-0051 for a National Functional Genomics Center, the National Cancer Institute under Award No. P30-CA076292 as a Cancer Center Support Grant, and the Moffitt Foundation. The triple quadrupole mass spectrometer was purchased with a shared instrument grant from the Bankhead-Coley Cancer Research program of the Florida Department of Health (06BS-02-9614).

\section{REFERENCES}

1. Davies H, Bignell GR, Cox C, Stephens P, Edkins S, Clegg S, Teague J, Woffendin H, Garnett MJ, Bottomley W, Davis N, Dicks E, Ewing R, Floyd Y, Gray K, Hall S et al. Mutations of the BRAF gene in human cancer. Nature. 2002; 417:949-954.

2. Dankort D, Curley DP, Cartlidge RA, Nelson B, Karnezis AN, Damsky Jr WE, You MJ, Depinho RA, McMahon M, Bosenberg M. Braf(V600E) cooperates with Pten loss to induce metastatic melanoma. Nat Genet. 2009.

3. Wellbrock C, Ogilvie L, Hedley D, Karasarides M, Martin J, Niculescu-Duvaz D, Springer CJ, Marais R. V599EBRAF is an oncogene in melanocytes. Cancer Res. 2004; 64:2338-2342.

4. Bhatt KV, Spofford LS, Aram G, McMullen M, Pumiglia $\mathrm{K}$, Aplin AE. Adhesion control of cyclin D1 and p27Kip1 levels is deregulated in melanoma cells through BRAFMEK-ERK signaling. Oncogene. 2005; 24:3459-3471.

5. Solit DB, Garraway LA, Pratilas CA, Sawai A, Getz G, Basso A, Ye Q, Lobo JM, She Y, Osman I, Golub TR, 
Sebolt-Leopold J, Sellers WR, Rosen N. BRAF mutation predicts sensitivity to MEK inhibition. Nature. 2006; 439:358-362.

6. Boisvert-Adamo K, Aplin AE. Mutant B-RAF mediates resistance to anoikis via Bad and Bim. Oncogene. 2008; 27:3301-3312.

7. Cartlidge RA, Thomas GR, Cagnol S, Jong KA, Molton SA, Finch AJ, McMahon M. Oncogenic BRAF(V600E) inhibits BIM expression to promote melanoma cell survival. Pigment Cell Melanoma Res. 2008; 21:534-544.

8. Klein RM, Aplin AE. Rnd3 regulation of the actin cytoskeleton promotes melanoma migration and invasive outgrowth in three dimensions. Cancer Res. 2009; 69:22242233.

9. Arozarena I, Sanchez-Laorden B, Packer L, HidalgoCarcedo C, Hayward R, Viros A, Sahai E, Marais R. Oncogenic BRAF induces melanoma cell invasion by downregulating the cGMP-specific phosphodiesterase PDE5A. Cancer Cell. 2011; 19:45-57.

10. Long GV, Menzies AM, Nagrial AM, Haydu LE, Hamilton AL, Mann GJ, Hughes TM, Thompson JF, Scolyer RA, Kefford RF. Prognostic and Clinicopathologic Associations of Oncogenic BRAF in Metastatic Melanoma. J Clin Oncol. 2011.

11. Smalley KS, Lioni M, Palma MD, Xiao M, Desai B, Egyhazi S, Hansson J, Wu H, King AJ, Van Belle P, Elder DE, Flaherty KT, Herlyn M, Nathanson KL. Increased cyclin D1 expression can mediate BRAF inhibitor resistance in BRAF V600E-mutated melanomas. Mol Cancer Ther. 2008; 7:2876-2883.

12. Montagut C, Sharma SV, Shioda T, McDermott U, Ulman M, Ulkus LE, Dias-Santagata D, Stubbs H, Lee DY, Singh A, Drew L, Haber DA, Settleman J. Elevated CRAF as a potential mechanism of acquired resistance to BRAF inhibition in melanoma. Cancer Res. 2008; 68:4853-4861.

13. Bollag G, Hirth P, Tsai J, Zhang J, Ibrahim PN, Cho H, Spevak W, Zhang C, Zhang Y, Habets G, Burton EA, Wong B, Tsang G, West BL, Powell B, Shellooe R et al. Clinical efficacy of a RAF inhibitor needs broad target blockade in BRAF-mutant melanoma. Nature. 2010.

14. Kefford R, Arkenau H, Brown MP, Millward M, Infante JR, Long GV, Ouellette D, Curtis M, Lebowitz PF, Falchook GS. Phase I/II study of GSK2118436, a selective inhibitor of oncogenic mutant BRAF kinase, in patients with metastatic melanoma and other solid tumors. Journal of Clinical Oncology. 2010; 28:8503.

15. Tsai J, Lee JT, Wang W, Zhang J, Cho H, Mamo S, Bremer R, Gillette S, Kong J, Haass NK, Sproesser K, Li L, Smalley KS, Fong D, Zhu YL, Marimuthu A et al. Discovery of a selective inhibitor of oncogenic B-Raf kinase with potent antimelanoma activity. Proc Natl Acad Sci U S A. 2008.

16. Joseph EW, Pratilas CA, Poulikakos PI, Tadi M, Wang W, Taylor BS, Halilovic E, Persaud Y, Xing F, Viale A, Tsai J, Chapman PB, Bollag G, Solit DB, Rosen N. The RAF inhibitor PLX4032 inhibits ERK signaling and tumor cell proliferation in a V600E BRAF-selective manner. Proc Natl Acad Sci U S A. 2010; 107:14903-14908.

17. Paraiso KH, Fedorenko IV, Cantini LP, Munko AC, Hall M, Sondak VK, Messina JL, Flaherty KT, Smalley KS. Recovery of phospho-ERK activity allows melanoma cells to escape from BRAF inhibitor therapy. Br J Cancer. 2010; 102:1724-1730.

18. Sondergaard JN, Nazarian R, Wang Q, Guo D, Hsueh T, Mok S, Sazegar H, MacConaill LE, Barretina JG, Kehoe SM, Attar N, von Euw E, Zuckerman JE, Chmielowski B, Comin-Anduix B, Koya RC et al. Differential sensitivity of melanoma cell lines with BRAFV600E mutation to the specific Raf inhibitor PLX4032. J Transl Med. 2010; 8:39.

19. Tap WD, Gong KW, Dering J, Tseng Y, Ginther C, Pauletti G, Glaspy JA, Essner R, Bollag G, Hirth P, Zhang C, Slamon DJ. Pharmacodynamic characterization of the efficacy signals due to selective BRAF inhibition with PLX4032 in malignant melanoma. Neoplasia. 2010; 12:637-649.

20. Flaherty KT, Puzanov I, Kim KB, Ribas A, MacArthur GA, Sosman JA, O'Dwyer PJ, Lee RJ, Grippo JF, Nolop $\mathrm{K}$, Chapman PB. Inhibition of mutated, activated BRAF in metastatic melanoma. N Engl J Med. 2010; 363:809-819.

21. Hersey P, Smalley KS, Weeraratna A, Bosenberg M, Zhang XD, Haass NK, Paton E, Mann G, Scolyer RA. Meeting report from the 7th International Melanoma Congress, Sydney, November, 2010. Pigment Cell Melanoma Res. 2011; 24:e1-15.

22. Nazarian R, Shi H, Wang Q, Kong X, Koya RC, Lee H, Chen Z, Lee MK, Attar N, Sazegar H, Chodon T, Nelson SF, McArthur G, Sosman JA, Ribas A, Lo RS. Melanomas acquire resistance to B-RAF(V600E) inhibition by RTK or N-RAS upregulation. Nature. 2010.

23. Villanueva J, Vultur A, Lee JT, Somasundaram R, Fukunaga-Kalabis M, Cipolla AK, Wubbenhorst B, Xu X, Gimotty PA, Kee D, Santiago-Walker AE, Letrero R, D'Andrea K, Pushparajan A, Hayden JE, Brown KD et al. Acquired resistance to BRAF inhibitors mediated by a RAF kinase switch in melanoma can be overcome by cotargeting MEK and IGF-1R/PI3K. Cancer Cell. 2010; 18:683-695.

24. Johannessen CM, Boehm JS, Kim SY, Thomas SR, Wardwell L, Johnson LA, Emery CM, Stransky N, Cogdill AP, Barretina J, Caponigro G, Hieronymus H, Murray RR, Salehi-Ashtiani K, Hill DE, Vidal M et al. COT drives resistance to RAF inhibition through MAP kinase pathway reactivation. Nature. 2010.

25. Wagle N, Emery C, Berger MF, Davis MJ, Sawyer A, Pochanard P, Kehoe SM, Johannessen CM, Macconaill LE, Hahn WC, Meyerson M, Garraway LA. Dissecting Therapeutic Resistance to RAF Inhibition in Melanoma by Tumor Genomic Profiling. J Clin Oncol. 2011.

26. Jiang CC, Lai F, Thorne RF, Yang F, Liu H, Hersey P, Zhang XD. MEK-Independent Survival of B-RAFV600E Melanoma Cells Selected for Resistance to Apoptosis Induced by the RAF Inhibitor PLX4720. Clin Cancer Res. 
2010.

27. Smalley KS, Haass NK, Brafford PA, Lioni M, Flaherty KT, Herlyn M. Multiple signaling pathways must be targeted to overcome drug resistance in cell lines derived from melanoma metastases. Mol Cancer Ther. 2006; 5:1136-1144.

28. Madhunapantula SV, Robertson GP. The PTEN-AKT3 signaling cascade as a therapeutic target in melanoma. Pigment Cell Melanoma Res. 2009; 22:400-419.

29. Paraiso KH, Xiang Y, Rebecca VW, Abel EV, Chen YA, Munko AC, Wood E, Fedorenko IV, Sondak VK, Anderson AR, Ribas A, Palma MD, Nathanson KL, Koomen JM, Messina JL, Smalley KS. PTEN Loss Confers BRAF Inhibitor Resistance to Melanoma Cells through the Suppression of BIM Expression. Cancer Res. 2011; 71:2750-2760.

30. Kusmierz JJ, Sumrada R, Desiderio DM. Fast atom bombardment mass spectrometric quantitative analysis of methionine-enkephalin in human pituitary tissues. Anal Chem. 1990; 62:2395-2400.

31. Barr JR, Maggio VL, Patterson DG, Jr., Cooper GR, Henderson LO, Turner WE, Smith SJ, Hannon WH, Needham LL, Sampson EJ. Isotope dilution--mass spectrometric quantification of specific proteins: model application with apolipoprotein A-I. Clin Chem. 1996; 42:1676-1682.

32. Barnidge DR, Dratz EA, Martin T, Bonilla LE, Moran LB, Lindall A. Absolute quantification of the $\mathrm{G}$ protein-coupled receptor rhodopsin by $\mathrm{LC} / \mathrm{MS} / \mathrm{MS}$ using proteolysis product peptides and synthetic peptide standards. Anal Chem. 2003; 75:445-451.

33. Barnidge DR, Goodmanson MK, Klee GG, Muddiman DC. Absolute quantification of the model biomarker prostate-specific antigen in serum by LC-Ms/MS using protein cleavage and isotope dilution mass spectrometry. J Proteome Res. 2004; 3:644-652.

34. Gerber SA, Rush J, Stemman O, Kirschner MW, Gygi SP. Absolute quantification of proteins and phosphoproteins from cell lysates by tandem MS. Proc Natl Acad Sci U S A. 2003; 100:6940-6945.

35. Anderson L, Hunter CL. Quantitative mass spectrometric multiple reaction monitoring assays for major plasma proteins. Mol Cell Proteomics. 2006; 5:573-588.

36. Rifai N, Gillette MA, Carr SA. Protein biomarker discovery and validation: the long and uncertain path to clinical utility. Nat Biotechnol. 2006; 24:971-983.

37. Kirsch S, Widart J, Louette J, Focant JF, De Pauw E. Development of an absolute quantification method targeting growth hormone biomarkers using liquid chromatography coupled to isotope dilution mass spectrometry. J Chromatogr A. 2007; 1153:300-306.

38. Kuzyk MA, Smith D, Yang J, Cross TJ, Jackson AM, Hardie DB, Anderson NL, Borchers CH. Multiple reaction monitoring-based, multiplexed, absolute quantitation of
45 proteins in human plasma. Mol Cell Proteomics. 2009; 8:1860-1877.

39. Whiteaker JR, Zhang H, Zhao L, Wang P, Kelly-Spratt KS, Ivey RG, Piening BD, Feng L-C, Kasarda E, Gurley KE, Eng JK, Chodosh LA, Kemp CJ, McIntosh MW, Paulovich AG. Integrated pipeline for mass spectrometry-based discovery and confirmation of biomarkers demonstrated in a mouse model of breast cancer. Journal of proteome research. 2007; 6:3962-3975.

40. Ahmed N, Thornalley PJ. Quantitative screening of protein biomarkers of early glycation, advanced glycation, oxidation and nitrosation in cellular and extracellular proteins by tandem mass spectrometry multiple reaction monitoring. Biochem Soc Trans. 2003; 31:1417-1422.

41. Jin LL, Tong J, Prakash A, Peterman SM, St-Germain JR, Taylor P, Trudel S, Moran MF. Measurement of protein phosphorylation stoichiometry by selected reaction monitoring mass spectrometry. J Proteome Res. 2010; 9:2752-2761.

42. Wolf-Yadlin A, Hautaniemi S, Lauffenburger DA, White FM. Multiple reaction monitoring for robust quantitative proteomic analysis of cellular signaling networks. Proc Natl Acad Sci U S A. 2007; 104:5860-5865.

43. Ley R, Ewings KE, Hadfield K, Cook SJ. Regulatory phosphorylation of Bim: sorting out the ERK from the JNK. Cell Death Differ. 2005; 12:1008-1014.

44. O'Connor L, Strasser A, O'Reilly LA, Hausmann G, Adams JM, Cory S, Huang DC. Bim: a novel member of the Bcl-2 family that promotes apoptosis. Embo J. 1998; 17:384-395.

45. Hsu SY, Lin P, Hsueh AJ. BOD (Bcl-2-related ovarian death gene) is an ovarian $\mathrm{BH} 3$ domain-containing proapoptotic Bcl-2 protein capable of dimerization with diverse antiapoptotic Bcl-2 members. Molecular endocrinology (Baltimore, Md. 1998; 12:1432-1440.

46. Boisvert-Adamo K, Longmate W, Abel EV, Aplin AE. Mcl-1 is required for melanoma cell resistance to anoikis. Mol Cancer Res. 2009; 7:549-556.

47. VanBrocklin MW, Verhaegen M, Soengas MS, Holmen SL. Mitogen-activated protein kinase inhibition induces translocation of Bmf to promote apoptosis in melanoma. Cancer Res. 2009; 69:1985-1994.

48. Gopal YN, Deng W, Woodman SE, Komurov K, Ram P, Smith PD, Davies MA. Basal and treatment-induced activation of AKT mediates resistance to cell death by AZD6244 (ARRY-142886) in Braf-mutant human cutaneous melanoma cells. Cancer Res. 2010; 70:87368747.

49. Shao Y, Aplin AE. Akt3-mediated resistance to apoptosis in B-RAF-targeted melanoma cells. Cancer Res. 2010; 70:6670-6681.

50. Wang Q, Chaerkady R, Wu J, Hwang HJ, Papadopoulos N, Kopelovich L, Maitra A, Matthaei H, Eshleman JR, Hruban RH, Kinzler KW, Pandey A, Vogelstein B. Mutant proteins 
as cancer-specific biomarkers. Proceedings of the National Academy of Sciences of the United States of America. 2011; 108:2444-2449.

51. Hoofnagle AN, Wener MH. The fundamental flaws of immunoassays and potential solutions using tandem mass spectrometry. J Immunol Methods. 2009; 347:3-11. 